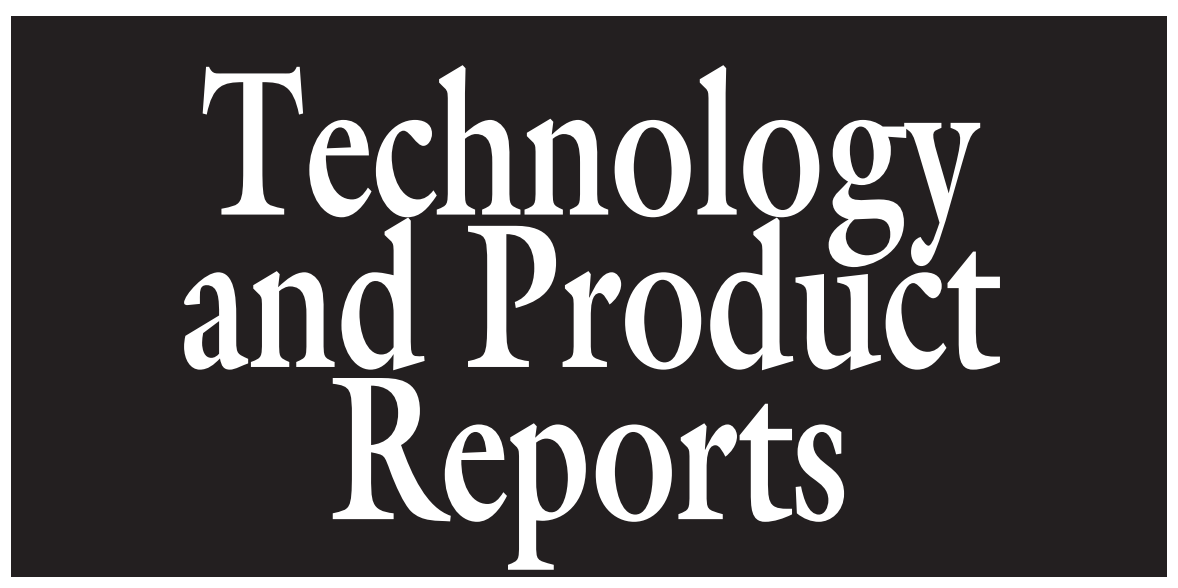

\title{
Effects of Bifenthrin on Mycorrhizal Colonization and Growth of Corn
}

\author{
Lea Corkidi ${ }^{1}$, Jeff Bohn, and Mike Evans
}

AdDITIONAL INDEX wORDs. insecticides, Zea mays

SUMMARY. The insecticide bifenthrin is a synthetic pyrethroid required by regulation for the production of nursery crops to suppress the red imported fire ant (Solenopsis invicta) in Orange and Riverside counties in California. We conducted a greenhouse experiment to analyze the effects of different rates of bifenthrin on the growth and mycorrhizal colonization of 'Silver Queen' corn (Zea mays) inoculated with VAM $80^{\circledR}$, a mycorrhizal inoculum with spores, hyphae, and root pieces colonized by Glomus spp., used to inoculate California native plants in containers. Corn was used because it is the standard indicator plant used for mycorrhizal inoculum potential assays and it is a good host for arbuscular mycorrhizal fungi propagation. The application of bifenthrin had no detrimental effects on mycorrhizal colonization of corn. There were no significant differences in the root length colonized by arbuscules, vesicles, or in the total percentage of mycorrhizal colonization obtained in the plants grown with the different bifenthrin rates 6 weeks after transplanting. However, there were significant interactions on the effects of bifenthrin and mycorrhizal colonization on plant growth. The addition of 12,15 , and $25 \mathrm{ppm}$ of bifenthrin reduced corn biomass of nonmycorrhizal plants, but had no effect on the growth of mycorrhizal plants. There were no significant differences between the mycorrhizal and nonmycorrhizal plants grown with 0,10 , and $12 \mathrm{ppm}$ of bifenthrin. In contrast, inoculation with VAM $80^{\circledR}$ increased the shoot dry weight of plants grown with 15 and $25 \mathrm{ppm}$ of bifenthrin. This study showed that mycorrhizal colonization can be helpful to overcome some of the negative effects of bifenthrin on the growth of corn.

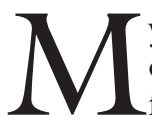
ycorrhizal colonization may offer a number of benefits to horticultural crops (Azcón-Aguilar and Barea, 1997;

Tree of Life Nursery, P.O. Box 635, San Juan Capistrano, CA 92693

We thank Ramiro Rodríguez, Salvador Zamarripa, Sinfarrosa Tampa, and Robert Camp for technical assistance. We would also like to thank Edith B. Allen, Gene Ratcliffe, and Sheila Bhattacharya for carefully reviewing this manuscript and for their valuable suggestions.

The mention of a trademark, proprietary product, or vendor does not constitute a guarantee or warranty of the product by the U.S. Department of Agriculture and does not imply its approval to the exclusion of other products or vendors that may also be suitable.

${ }^{1}$ Corresponding author. E-mail: lcorkidi@aol.com.
Larsen et al., 2007). It has been shown that several commercial mycorrhizal inoculants enhance plant growth during nursery container production (Carpio et al., 2003) and improve cuttings' rooting and survival (Druege et al., 2006). Plants colonized by arbuscular mycorrhizal (AM) fungi are also more efficient in nutrient uptake, more resistant to soil-borne pathogens, and more tolerant to transplanting shock (Azcón-Aguilar and Barea, 1997). However, nursery operations are often subjected to regulations that may affect mycorrhizal colonization, such as the use of certain pesticides (California Department of Food and Agriculture, 2009).

The effects of pesticides on mycorrhizal colonization vary from beneficial to detrimental. While several chemicals inhibit the development of mycorrhizal associations, others do not affect the symbiosis, and the use of certain pesticides even stimulate root colonization by AM fungi and increase their sporulation (Menge, 1982; Trappe et al., 1984). In some cases, contradictory results have been obtained with the same chemical products because the effects of pesticides on mycorrhizal colonization are influenced by the combination of plant species, AM fungi species, pesticide, and dose of application (Sainz et al., 2006; Schweiger and Jakobsen, 1998). Therefore, in horticultural management practices that include the use of AM fungi, it is important to assess the impact of pesticides on the mycorrhizal association.

The insecticide bifenthrin is a synthetic pyrethroid used for the production of nursery crops to suppress the red imported fire ant in quarantined areas of Orange and Riverside counties in California (California Department of Pesticide Regulation, 2009). Contrasting results have been reported on the effects of other synthetic pyrethroids on root colonization by AM fungi. The application of cypermethrin caused significant reduction on the mycorrhizal colonization of peanut (Arachis hypogaea), but high concentrations of

\begin{tabular}{llll}
\hline $\begin{array}{l}\text { Units } \\
\text { To convert U.S. to SI, } \\
\text { multiply by }\end{array}$ & U.S. unit & SI unit & $\begin{array}{l}\text { To convert SI to U.S., } \\
\text { multiply by }\end{array}$ \\
\hline 2.54 & inch(es) & $\mathrm{cm}$ & 0.3937 \\
16.3871 & inch $^{3}$ & $\mathrm{~cm}^{3}$ & 0.0610 \\
0.5933 & $\mathrm{lb} / \mathrm{yard}^{3}$ & $\mathrm{~kg} \cdot \mathrm{m}^{-3}$ & 1.6856 \\
28.3495 & $\mathrm{oz}$ & $\mathrm{g}$ & 0.0353 \\
1 & $\mathrm{ppm}$ & $\mathrm{mg} \cdot \mathrm{kg}^{-1}$ & 1 \\
$\left({ }^{\circ} \mathrm{F}-32\right) \div 1.8$ & ${ }^{\circ} \mathrm{F}$ & ${ }^{\circ} \mathrm{C}$ & $\left(1.8 \times{ }^{\circ} \mathrm{C}\right)+32$
\end{tabular}


fenvalerate did not affect the symbiosis and the percentage of mycorrhizal colonization increased when it was applied at concentrations of 5 and $10 \mathrm{ppm}$ (Vijayalakshmi and Rao, 1993). The objective of this study was to determine the effects of bifenthrin on the growth and mycorrhizal colonization of corn inoculated with VAM $80^{\circledR}$ (Tree of Life Nursery, San Juan Capistrano, CA), a mycorrhizal inoculum that is propagated for largescale inoculation of California native plants in containers.

\section{Materials and methods}

The effects of bifenthrin on plant growth and mycorrhizal colonization were compared in a bioassay conducted with 'Silver Queen' corn, the standard indicator plant used for mycorrhizal inoculum potential assays (Moorman and Reeves, 1979) and a good host for AM fungi propagation. Mycorrhizal and nonmycorrhizal corn plants were grown with several rates of bifenthrin in the greenhouse of Tree of Life Nursery in San Juan Capistrano, CA, from Oct. to Nov. 2002. Average high/ low temperatures were $23 / 4{ }^{\circ} \mathrm{C}$ (day/night).

GROWING MEDIUM, BIFENTHRIN RATES, AND MYCORRHIZAL INOCULATION. Corn plants were grown in a mix prepared with 2 calcined clay: 1 silica sand (by volume), one of the growing media used for VAM $80^{\circledR}$ propagation at Tree of Life Nursery. This medium was mixed in a cement mixer with $2 \mathrm{lb} /$ yard $^{3}$ of Sierra micro$\max ^{\circledR}$ trace element mix (Scotts-Sierra Horticultural Products, Marysville, $\mathrm{OH}$ ) and $1 \mathrm{lb} /$ yard $^{3}$ of $18 \mathrm{~N}-2.6 \mathrm{P}-$ 9.9K Osmocote ${ }^{\circledR}$ controlled-release fertilizer (Scotts Co., Marysville, $\mathrm{OH}$ ). Five different mixes were prepared with this medium adding no bifenthrin, or $10,12,15$, and $25 \mathrm{ppm}$ a.i. bifenthrin $(5.38,6.45,8.07$, and $13.45 \mathrm{lb} /$ yard $^{3}$, respectively, of Talstar nursery granular insecticide; FMC Corp., Philadelphia, PA). These are the rates specified in the Talstar ${ }^{\circledR}$ specimen label to provide protection against imported fire ant for 0 to 6 months, 7 to 12 months, 13 to 24 months, and continuous protection, respectively.

Twenty Deepots ${ }^{\mathrm{TM}}\left(40\right.$-inch $^{3}$ plastic containers, 10 inches deep $\times$ 2.5 inches diameter; Stuewe and Sons, Corvallis, OR) were filled with each of the mixes. Ten were left as nonmycorrhizal controls and 10 were inoculated with a layer of VAM $80^{\circledR}$ placed 6 to $8 \mathrm{~cm}$ from the top of the container. VAM $80^{\circledR}$ consists of spores, hyphae, and root fragments colonized by a species of Glomus that sporulates intraradically, and it contains at least 60 propagules $/ \mathrm{cm}^{3}$. One 5 -d-old pregerminated corn seedling was transplanted into each container. Two support trays with 10 Deepots ${ }^{\mathrm{TM}}$ per treatment were randomly distributed in the greenhouse bench and rotated weekly.

Harvests. Five randomly selected plants per treatment were harvested 3 and 6 weeks after transplanting. Shoots were separated from roots and were oven-dried at $70{ }^{\circ} \mathrm{C}$ and then weighed. Root systems were divided in two parts and the fresh weight was determined on both. A subsample of the root system was maintained fresh and was used to assess the percentage of mycorrhizal colonization. The remaining part was oven-dried and weighed. Total root dry weight was calculated based on fresh-to-dry weight relationships.

Fresh root pieces were cleared and stained using the technique of Koske and Gemma (1989), and 50 $\mathrm{l}-\mathrm{cm}$-long root pieces were mounted in polyvinyl alcohol lacto-glycerol on microscope slides. The percentage of mycorrhizal colonization was determined in 100 intersections by the magnified intersection method of McGonigle et al. (1990).

Data Analysis. Two-way analysis of variance (ANOVA) with bifenthrin rate and mycorrhizal inoculum as factors was performed on plant growth (root, shoot, total dry mass, and root:shoot ratio). One-way ANOVA was used to analyze significant differences among bifenthrin rates in each inoculum treatment, and differences between mycorrhizal and nonmycorhizal plants in each bifenthrin rate were analyzed with the Student's $t$ test. The percentages of mycorrhizal colonization (by arbuscules, vesicles, and total) were arcsine-square root-transformed and subjected to one-way ANOVA. Mean contrasts were performed using Fisher's protected least significant difference with $P \leq 0.05$ as the level of significance (Zar, 1996).

\section{Results}

EFFECTS OF BIFENTHRIN ON MYCORRHIZAL COLONIZATION. Mycorrhizal colonization at the first harvest was too low to be analyzed (data not shown). Six weeks after transplanting, there were no significant differences in the percentage of mycorrhizal colonization of plants grown without bifenthrin or with different rates of bifenthrin (root length colonized by arbuscules, vesicles, and total percentage of mycorrhizal colonization) (Table 1 ). Corn plants grown with 25 ppm of bifenthrin tended to have a lower percentage of arbuscules than those grown with $0,10,12$, or $15 \mathrm{ppm}$, but the difference was not statistically significant (Table 1).

EFFECTS OF BIFENTHRIN ON PLANT GROWTH. There were no significant differences in root, shoot, total dry weight, and root:shoot ratio between mycorrhizal and nonmycorrhizal corn plants grown without

Table 1. Total percentage of mycorrhizal colonization and percentage of arbuscules and vesicles in plants of 'Silver Queen' corn inoculated VAM 80 ${ }^{\circledR}$ (mycorrhizal inoculum with spores, hyphae, and root pieces colonized by Glomus spp.; Tree of Life Nursery, San Juan Capistrano, CA) 6 weeks after transplanting.

\begin{tabular}{lcrr}
\hline $\begin{array}{l}\text { Bifenthrin } \\
\text { rate }(\mathbf{p p m})^{\mathrm{z}}\end{array}$ & $\begin{array}{l}\text { Mycorrhizal } \\
\text { colonization }\end{array}$ & Arbuscules & Vesicles \\
\cline { 2 - 4 } & & mean \pm SE $(\%)^{\mathrm{y}}$ & \\
\hline 0 & $40.2 \pm 5.1$ & $9.0 \pm 2.3$ & $28.7 \pm 5.0$ \\
10 & $38.7 \pm 8.8$ & $10.2 \pm 2.1$ & $30.7 \pm 7.8$ \\
12 & $36.0 \pm 6.9$ & $7.5 \pm 3.6$ & $29.9 \pm 5.8$ \\
15 & $41.3 \pm 7.2$ & $8.9 \pm 3.3$ & $36.6 \pm 7.0$ \\
25 & $35.5 \pm 6.3$ & $2.7 \pm 1.6$ & $29.7 \pm 5.6$ \\
\hline
\end{tabular}

${ }^{\mathrm{z}} \mathrm{l} \mathrm{ppm}=\mathrm{l} \mathrm{mg} \cdot \mathrm{kg}^{-1}$

${ }^{y}$ Mean \pm SE of five replicates. There were no statistically significant differences among the total percentages of mycorrhizal colonization, percentage of arbuscules and vesicles of corn grown without bifenthrin, or with different rates of bifenthrin. 
bifenthrin and with the different rates of bifenthrin at the first harvest (data not shown).

At the second harvest, the twoway ANOVA indicated significant interactions in the effect of bifenthrin and mycorrhizal inoculum in corn shoot, root, and total dry weight. The addition of bifenthrin reduced corn biomass of nonmycorrhizal plants but had no effect on the growth of mycorrhizal plants. Nonmycorrhizal corn plants grown with 12,15 , and 25 ppm of bifenthrin had lower shoot, root, and total dry weight than those grown without or with $10 \mathrm{ppm}$ of bifenthrin (Table 2). In contrast, there were no significant differences in the shoot, root, and total dry weight of mycorrhizal plants grown without bifenthrin or with its different rates (Table 2).

There were no significant differences between the dry weight produced by mycorrhizal and nonmycorrhizal plants grown with 0,10 , and $12 \mathrm{ppm}$ of bifenthrin. However, inoculation with VAM $80^{\circledR}$ increased

Table 2. Shoot, root, and total dry weight, and root:shoot of mycorrhizal and nonmycorrhizal plants of corn grown with $0,10,12,15$, and $25 \mathrm{ppm}$ bifenthrin insecticide 6 weeks after transplanting.

\begin{tabular}{|c|c|c|c|c|}
\hline \multirow{2}{*}{$\begin{array}{l}\text { Response } \\
\text { variable }\end{array}$} & \multirow{2}{*}{$\begin{array}{l}\text { Bifenthrin } \\
\text { rate }(\mathrm{ppm})^{\mathrm{z}}\end{array}$} & Nonmycorrhizal $^{y}$ & Mycorrhizal & \multirow{2}{*}{$\begin{array}{l}\text { Mycorrhizal vs. } \\
\text { nonmycorrhizal }\end{array}$} \\
\hline & & \multicolumn{2}{|c|}{ mean $\pm \mathrm{SE}^{\mathrm{x}}$} & \\
\hline \multirow[t]{5}{*}{ Shoot dry wt $(\mathrm{g})^{\mathrm{z}}$} & 0 & $1.00 \pm 0.066 \mathrm{a}$ & $1.02 \pm 0.219 \mathrm{a}$ & $\mathrm{NS}^{\mathrm{w}}$ \\
\hline & 10 & $1.03 \pm 0.080 \mathrm{a}$ & $0.87 \pm 0.067 \mathrm{a}$ & NS \\
\hline & 12 & $0.8 \mathrm{l} \pm 0.045 \mathrm{~b}$ & $0.84 \pm 0.105 \mathrm{a}$ & NS \\
\hline & 15 & $0.81 \pm 0.048 \mathrm{~b}$ & $1.24 \pm 0.111 \mathrm{a}$ & ** \\
\hline & 25 & $0.77 \pm 0.037 \mathrm{~b}$ & $1.20 \pm 0.087 \mathrm{a}$ & ** \\
\hline \multirow[t]{5}{*}{ Root dry wt (g) } & 0 & $0.79 \pm 0.063 \mathrm{a}$ & $0.48 \pm 0.087 \mathrm{a}$ & ** \\
\hline & 10 & $0.73 \pm 0.046 \mathrm{ac}$ & $0.54 \pm 0.026 \mathrm{a}$ & ** \\
\hline & 12 & $0.60 \pm 0.041 \mathrm{bc}$ & $0.42 \pm 0.031 \mathrm{a}$ & ** \\
\hline & 15 & $0.51 \pm 0.034 b$ & $0.59 \pm 0.027 \mathrm{ab}$ & NS \\
\hline & 25 & $0.53 \pm 0.035 \mathrm{~b}$ & $0.63 \pm 0.047 \mathrm{ab}$ & NS \\
\hline \multirow[t]{5}{*}{ Total dry wt (g) } & 0 & $1.79 \pm 0.108 \mathrm{a}$ & $1.50 \pm 0.306 \mathrm{a}$ & NS \\
\hline & 10 & $1.76 \pm 0.113 \mathrm{a}$ & $1.41 \pm 0.089 \mathrm{a}$ & * \\
\hline & 12 & $1.34 \pm 0.068 \mathrm{~b}$ & $1.26 \pm 0.131 \mathrm{a}$ & NS \\
\hline & 15 & $1.32 \pm 0.079 \mathrm{~b}$ & $1.83 \pm 0.123 \mathrm{a}$ & * \\
\hline & 25 & $1.30 \pm 0.067 \mathrm{~b}$ & $1.83 \pm 0.134 \mathrm{a}$ & * \\
\hline \multirow[t]{5}{*}{ Root:shoot (ratio) } & 0 & $0.81 \pm 0.075 \mathrm{a}$ & $0.49 \pm 0.019 \mathrm{a}$ & * \\
\hline & 10 & $0.73 \pm 0.054 \mathrm{ac}$ & $0.64 \pm 0.034 b$ & NS \\
\hline & 12 & $0.75 \pm 0.057 \mathrm{ac}$ & $0.53 \pm 0.050 \mathrm{a}$ & * \\
\hline & 15 & $0.63 \pm 0.023 b c$ & $0.49 \pm 0.086 \mathrm{a}$ & * \\
\hline & 25 & $0.70 \pm 0.034 \mathrm{ac}$ & $0.52 \pm 0.008 \mathrm{a}$ & ** \\
\hline
\end{tabular}

${ }^{\mathrm{z}} \mathrm{l} \mathrm{g}=0.0353 \mathrm{oz}, \mathrm{l} \mathrm{ppm}=1 \mathrm{mg} \cdot \mathrm{kg}^{-1}$.

${ }^{y}$ Mycorrhizal plants were inoculated with VAM $80^{\circledR}$ (Tree of Life Nursery, San Juan Capistrano, CA), a mycorrhizal inoculum with spores, hyphae, and root pieces colonized by Glomus spp.

${ }^{x}$ Data represent the mean \pm SE of five replicates. Means within a column followed by the same letter are not significantly different at $\alpha=0.05$ as determined by Fisher's protected least significant difference.

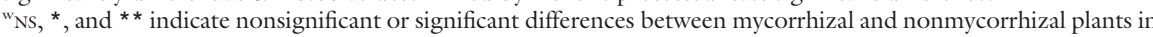
each bifenthrin rate (across rows) at $P \leq 0.05$ or $P \leq 0.001$, respectively, according to the Student's $t$ test. mycorrhizal inoculum (Klironomos and Hart, 2002). There were no differences between the percentages of vesicles found in plants grown without bifenthrin or with its different rates.

Several studies have shown that the effects of pesticides on mycorrhizal colonization vary with the plant species, the AM fungi species, and the dose of application (Menendez et al., 1999; Spokes et al., 1981). We have previously tested the effects of bifenthrin in different host plants and in different growing media. No significant differences were found in the percentages of mycorrhizal colonization of california sunflower (Encelia californica) and white sage (Salvia apiana) grown in a nursery mix composed of different barks with different rates of bifenthrin (Corkidi et al., 2002).

More studies are needed to determine what conditions caused plant sensitivity to bifenthrin. The addition of 12,15 , and $25 \mathrm{ppm}$ of bifenthrin reduced the growth of nonmycorrhizal corn plants. The synthetic pyrethroids, fenvalerate and cypermethrin, also reduced the dry weight of peanut (Vijayalakshmi and Rao, 1993), and the application of bifenthrin ECl0 caused slight damage to very young leaves of field roses [Rosa spp. (Gough, 1990)]. However, Knabke and Hancock (1990) did not find phytotoxic effects of Talstar ${ }^{\circledR}$ loWP in over 100 different species grown in the field and greenhouse, nor did Spiers et al. (2006) in 'Festival Salmon' gerbera (Gerbera jamesonii).

The question remains as to why mycorrhizal colonization increased the dry weight of the mycorrhizal plants grown with 15 and $25 \mathrm{ppm}$ of bifenthrin and helped to overcome the potential negative effects caused by bifenthrin on the growth of nonmycorrhizal plants. Other studies have also shown that mycorrhizal colonization reduced the phytotoxic effects of some pesticides (e.g., Sainz et al., 2006). However, the complex interactions of insecticides and mycorrhizal colonization on plant growth deserve further investigation because insecticides and AM fungi are also known to alter soil microbial communities and plant nutrient availability (Azcón-Aguilar and Barea, 1997; Das and Mukherjee, 2000). 


\section{Literature cited}

Azcón-Aguilar, C. and J.M. Barea. 1997. Applying mycorrhiza biotechnology to horticulture: Significance and potentials. Scientia Hort. 68:1-24.

California Department of Food and Agriculture. 2009. Red imported fire ants. 14 Apr. 2009. <http://www.cdfa.gov/ PHPPS/pdep/rifa/>.

California Department of Pesticide Regulation. 2009. Red imported fire ant project. 14 Apr. 2009. <http://www. cdpr.ca.gov/docs/emon/epests/rifa/>.

Carpio, L.A., F.T. Davies, Jr., and M.A. Arnold. 2003. Effect of commercial arbuscular mycorrhizal fungi on growth, survivability, and subsequent landscape performance of selected container grown nursery crops. J. Environ. Hort. 21:190195.

Corkidi, L., M. Evans, and J. Bohn. 2002. Effect of bifenthrin (Talstar $\left.{ }^{\circledR}\right)$ on mycorrhizal colonization of California native plants in containers. Combined Proc. Intl. Plant Prop. Soc. 52:604-608.

Das, A.C. and D. Mukherjee. 2000. Soil application of insecticides influences microorganisms and plant nutrients. Appl. Soil Ecol. 14:55-62.

Druege, U., M. Xylaender, S. Zerche, and H. von Alten. 2006. Rooting and vitality of poinsettia cuttings was increased by arbuscular mycorrhiza in the donor plants. Mycorrhiza 17:67-72.

Gough, N. 1990. Evaluation of miticides for the control of two-spotted mite Tetra- nychus urticae Koch on field roses in southern Queensland. Crop Prot. 9:119-127.

Klironomos, J.N. and M.M. Hart. 2002. Colonization of roots by arbuscular mycorrhizal fungi using different sources of inoculum. Mycorrhiza 12:181-184.

Koske, R.E. and J.N. Gemma. 1989. A modified procedure for staining roots to detect VA mycorrhizas. Mycol. Res. 92:486-505.

Knabke, J.J. and H.G. Hancock. 1990. Talstar insecticide/miticide formulations: A review of efficacy and phytotoxicity in ornamental use. HortScience 25:76. (Abstr.).

Larsen, J., S. Ravnskov, and J.N. Sorensen. 2007. Capturing the benefits of arbuscular mycorhizae in horticulture, p. 123-149. In: C. Hamel and C. Plenchette (eds.). Mycorrhizae in crop production. Haworth Press, New York, NY.

McGonigle, T.P., M.H. Miller, D.G. Evans, G.L. Fairchild, and J.A. Swan. 1990. A new method which gives an objective measure of colonization of roots by vesicular-arbuscular mycorrhizal fungi. New Phytol. 115:495-501.

Menendez, A., A. Martínez, V. Chiocchio, N. Venedikian, J.A. Ocampo, and A. Godeas. 1999. Influence of the insecticide dimethoate on arbuscular mycorrhizal colonization and growth in soybean plants. Int. Microbiol. 2:43-45.

Menge, J.A. 1982. Effects of soil fumigants and fungicides on vesicular-arbuscular fungi. Phytopathology 72:1126-1132.
Moorman, T. and F.B. Reeves. 1979. The role of endomycorrhizae in revegetation practices in the semiarid west. II. A bioassay to determine the effect of land disturbance on endomycorrhizal populations. Amer. J. Bot. 66:14-18.

Sainz, M.J., B. González-Penalta, and A. Vilariño. 2006. Effects of hexachlorocyclohexane on rhizosphere fungal propagules and root colonization by arbuscular mycorrhizal fungi in Plantago lanceolata. Eur. J. Soil Sci. 57:83-90.

Schweiger, P.F. and I. Jakobsen. 1998. Dose-response relationships between four pesticides and phosphorus uptake by hyphae of arbuscular mycorrhizas. Soil Biol. Biochem. 30:1415-1422.

Spiers, J.D., F.T. Davies, Jr., C. He, C.E. Bográn, K.M. Heinz, T.W. Starman, and A. Chau. 2006. Effects of insecticides on gas exchange, vegetative and floral development, and overall quality of gerbera. HortScience 41:701-706.

Spokes, J.R., R.M. MacDonald, and D.M. Hayman. 1981. Effects of plant protection chemicals on vesicular-arbuscular mycorrhizas. Pestic. Sci. 12:346-350.

Trappe, J.M., R. Molina, and M. Castellano. 1984. Reactions of mycorrhizal fungi and mycorrhiza formation to pesticides. Annu. Rev. Phytopathol. 22:331-359.

Vijayalakshmi, M. and A.S. Rao. 1993. Effects of six insecticides and one fungicide on the development of VAM fungi in peanut (Arachis bypogoea L.). Zentralbl. Mikrobiol. 148:60-65.

Zar, J.H. 1996. Biostatistical analysis. Prentice-Hall, Upper Saddle River, NJ. 